\section{Pathogenesis of gastrointestinal infection}

\author{
Alan Phillips PhD FRCPCH \\ Professor of Paediatric Gastroenterology, Centre for Paediatric \\ Gastroenterology, Royal Free Hospital, London
}

Email: a.phillips@medsch.ucl.ac.uk

I came to paediatric gastroenterology in the 1970s as a zoologist with an interest in structure and function. I was appointed as an electron microscopist at Queen Elizabeth Hospital for Children (QEHC) in London where it had been decided that an academic approach, rather than technical support, was required to optimise studies of childhood malabsorption.

\section{Non-bacterial gastroenteritis}

It is hard to believe, but in the 1970s viral gastroenteritis was not established, and presumed cases were termed 'non-bacterial'. This arose from a classic culture and isolation approach when gastrointestinal viral culture was impossible. It is obvious in hindsight, but to see viruses high-resolution microscopy has to be used, and, indeed, this provided the breakthrough. The first report, from Australia, identified rotavirus in duodenal biopsies from children with acute gastroenteritis using transmission electron microscopy (EM). ${ }^{1}$ Stool EM found rotavirus excreted in huge numbers so that rapid diagnosis (within minutes) on minimally prepared faecal samples was possible (Fig 1). ${ }^{2,3}$ It also demonstrated other morphologically distinct viral particles, and in a short time non-bacterial gastroenteritis became divided up into rotavirus, adenovirus, Norwalk-like, or other viral diarrhoeas. ${ }^{4}$ These clear diagnoses opened up viral gastroenteritis, allowed 'virus-directed' clinical and epidemiological studies and gave rational explanations for diarrhoeal episodes. Stool EM was also important in dissecting out inter-current infections in inpatients, and fine-tuning diagnostic and treatment approaches. By the late 1970s we had set up a rapid stool EM diagnostic service and this formed the major workload of the virus laboratory at QEHC, particularly in the winter months. The pressures of economy and scale have moved stool virology away from EM towards immune-based antigen-recognition and molecular biological techniques, but the groundwork of the 1970s and 1980s culminated with the possibility of effective vaccines to control rotavirus gastroenteritis. ${ }^{5}$

\section{Escherichia coli}

The perceived technical complication of EM can produce hesitation in its application. So, although adult volunteer studies in the 1970s showed that the apparently non-invasive and non-toxigenic enteropathogenic Escherichia coli (EPEC) were diarrhoeal pathogens, it was only in 1980 that the distinctive, attachingeffacing lesion was seen by EM in a child with severe chronic diarrhoea (Fig 2). ${ }^{6}$ Such cases were common in the local area. ${ }^{7}$ The observation that host cell actin accumulated at sites of EPEC (and enterohaemorrhagic E coli (EHEC)) infection provided a host cell-based virulence test, ${ }^{8}$ which handed to molecular biologists the key that unlocked the incredible bacterial 'machinery' underlying pathogenesis. This machinery comprises a molecular needle which injects bacterial proteins into host cells, including an adhesion receptor and other molecules which variously affect host cell survival, permeability, and immune function. ${ }^{9}$ The full extent of this molecular piracy is still being elucidated, and the ability to reproduce the pathology in intestinal organ culture requires more studies of bacterial pathogenesis and host cell biology. ${ }^{10}$ Another key development was the recognition in the 1980s of a link between Shiga toxin in EHEC infections and haemorrhagic colitis and the haemolytic uraemic syndrome; ${ }^{11}$ importantly, allowing recognition of its role as a food-chain-associated infection at a time of centralisation and globalisation of food production, and now as a potential weapon in bioterrorism.

\section{Helicobacter pylori}

Enteropathogenic E coli infections are visible by light microscopy, but you have to recognise what is there, you have to

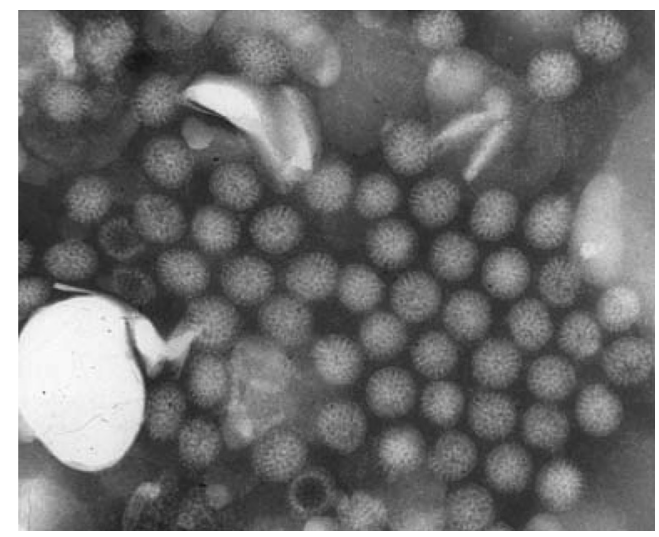

Fig 1. Rotavirus particles as seen by negative staining electron microscopy.

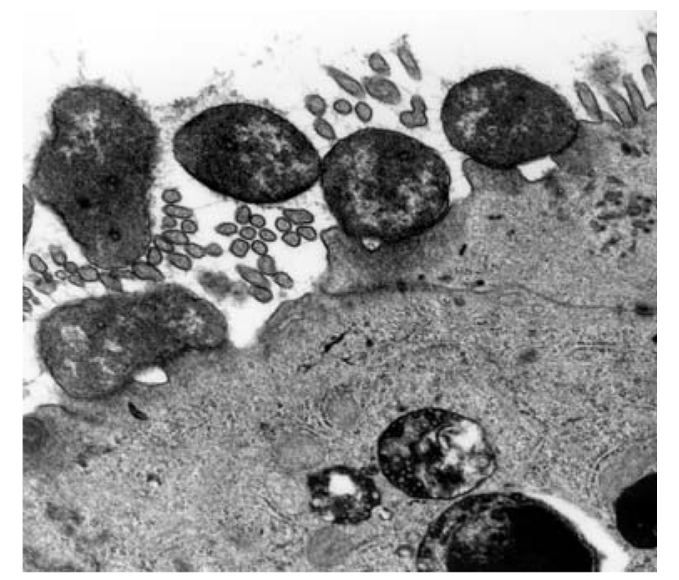

Fig 2. The distinctive transmission electron microscopy attaching-effacing lesion of enteropathogenic Escherichia coli adhering to the intestinal epithelium. 


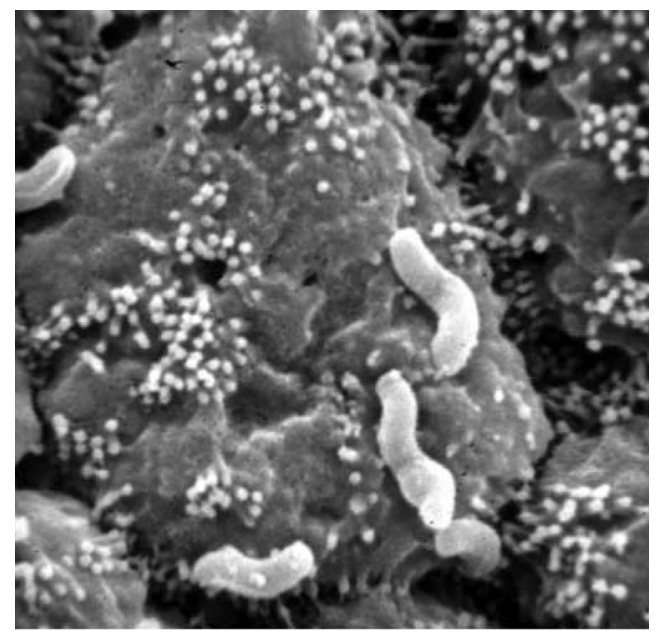

Fig 3. Scanning electron microscope appearance of Helicobacter pylori on the surface of metaplastic gastric mucus cells in the intestine.

believe what you see, and you have to convince other sceptical people. This mantra is particularly apposite with regard to gastric infection. It was intriguing to see spiral shaped bacteria, particularly in the stomach of untreated gastritis controls, in a study of gastric and duodenal ulcer healing at the time that Barry Marshall thrust Helicobacter pylori into the limelight (Fig 3). ${ }^{12,13}$ It is now accepted that it causes ulcer disease, but it required a sea-change of opinion to acknowledge that an organism could survive the acidic gastric environment. Marshall and Robin Warren were awarded the Nobel Prize in 2005 for this observation, giving a classical example of productive collaboration between clinician and laboratory scientist.

\section{Molecular biology}

Molecular biology has forced the pace recently in understanding pathogenesis. Procedures, such as genome sequencing, once daunting are now routine, affording genetic comparisons between related species; bioinformatics can predict candidate virulence genes, genes can be deleted, mutated, and/or transfected, and proteomics can screen for gene products of interest. These capabilities have necessarily brought checks and balances so that administrators who free researchers from the mounting burden of paperwork are increasingly important.

\section{Summary}

The last 30 years has seen the recognition of many intestinal pathogens, through a combination of microscopy, tissue availability and open minds. In the developing world the challenge to eradicate such infections continues, especially in infancy and early childhood. In developed communities, however, the challenge is shifting to pathogens ('super bugs') arising from our own interventions and lifestyles which will occupy many future careers.

\section{References}

1 Bishop RF, Davidson GP, Holmes IH, Ruck BJ. Virus particles in epithelial cells of duodenal mucosa from children with acute nonbacterial gastroenteritis. Lancet 1973;2:1281-3.

2 Flewett T, Bryden AS, Davies H. Virus particles in gastroenteritis. Lancet 1973;2:1497.

3 Rice SJ, Phillips AD. Rapid preparation of faecal specimens for detection of viral particles by electron microscopy. Med Lab Sci 1980;37:371-2.

4 Madeley CR. Viruses in the stools. J Clin Pathol 1979;32:1-10.

5 Lepage P, Vergison A. Prevention of childhood rotavirus disease through the use of Rotarix and RotaTeq vaccines. Expert Opin Biol Ther 2007;7:1881-92.

6 Ulshen MH, Rollo JL. Pathogenesis of Escherichia coli gastroenteritis in man - another mechanism. N Engl J Med 1980;302:99-101.

7 Hill SM, Phillips AD, Walker-Smith JA. Enteropathogenic E coli and life-threatening chronic diarrhoea. Gut 1991;32:154-8.

8 Knutton S, Baldwin T, Williams PH, McNeish AS. Actin accumulation at sites of bacterial adhesion to tissue culture cells: basis of a new diagnostic test for enteropathogenic and enterohemorrhagic Escherichia coli. Infect Immun 1989;57:1290-8.

9 Zaharik ML, Grunheid S, Perrin AJ, Finlay BB. Delivery of dangerous goods: type III secretion in enteric pathogens. Int J Med Microbiol 2002;291:593-603.

10 Hicks S, Frankel G, Kaper JB, Dougan G, Phillips AD. Role of intimin and bundle-forming pili in enteropathogenic Escherichia coli adhesion to pediatric intestinal tissue in vitro. Infect Immun 1998;66:1570-8.

11 Nataro JP, Kaper JB. Diarrheagenic Escherichia coli. Clin Microbiol Rev 1998;11:142-201.

12 Phillips AD, Hine KR, Holmes GKT, Woodings DF. Gastric spiral bacteria. Lancet 1984 ii:101-102.

13 Marshall BJ, Warren JR. Unidentified curved bacilli in the stomach of patients with gastritis and peptic ulceration. Lancet 1984;1:1311-5. 